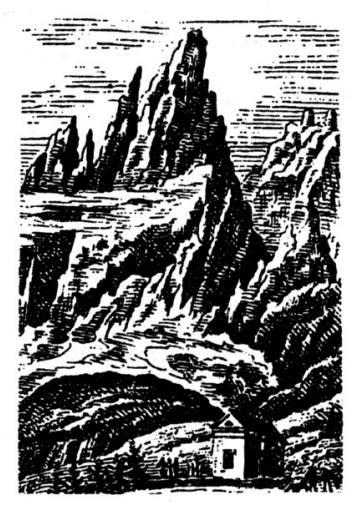

Małgorzata Łoboz

ORCID: 0000-0002-0705-8219

Uniwersytet Wrocławski

malgorzata.loboz@uwr.edu.pl

Marian Ursel

ORCID: 0000-0001-6952-9146

Uniwersytet Wrocławski

marian.ursel@uwr.edu.pl

https://doi.org/10.19195/2084-4107.15.19

\title{
„Za czarnych skał krawędzie...”. Góry zawłaszczone przez dekadentyzm w wybranych dziewiętnastowiecznych impresjach literacko-muzycznych
}

Słowa-klucze: W Szwajcarii Juliusza Słowackiego, Młoda Polska Tatrzańska, pieśni Mieczysława Karłowicza

Keywords: W Szwajcarii by Juliusz Słowacki, Young Poland and the Tatras, songs by Mieczysław Karłowicz 


\title{
"Za czarnych skat krawędzie...": The mountains appropriated by decadentism in selected nineteenth- century literary and musical impressions
}

\begin{abstract}
Summary
The article contains an analysis and interpretation of the significance of the mountains in artistic battles with decadent moods. The man that should be regarded as a precursor of such moods is Juliusz Słowacki. He is the author of the well-known poem W Szwajcarii (In Switzerland, 1839), from which comes the passage included in the title of the article: "Za czarnych skał krawędzie" (Behind the edges of black rocks), where the lyrical protagonist is heading - seeking self-annihilation - trying to find some relief in his suffering. This is the context in which Słowacki's passage was interpreted by Mieczysław Karłowicz - a representative of the Young Poland generation in music, one of the best known Polish composers, a photographer and mountaineer, who died in the Tatras in an avalanche in 1909.

In addition to Słowacki's piece, the authors of the article analyse also other songs by Karłowicz (which are not highly valued by musicologists), composed to words by well-known nineteenth-century Polish poets, mainly Kazimierz Przerwa-Tetmajer, a leading Polish exponent of decadentism in poetry. Karłowicz represented a neo-romantic version of modernism in music, which is why his oeuvre contains romantic analogies (emotionalism, mysticism, individualism, expression of the form), and his undoubtedly introverted and individualistic personality isolated him from generational associations already during his studies in Berlin. Nevertheless, he did identify with the Young Poland generation through a desire to achieve depression and deprivation defeating nirvana, to overcome death through the belief in the liberating power of nature. The mood of these works is marked by recurring (typically decadent) pessimism - a dominant feature of Karłowicz's music.

The authors conclude by observing that in the views of Polish modernists the mountains were a symbol of eternity and power of nature, a symbol juxtaposed with the fragility of human existence, an oasis of silence, peace and solitude, and thus human freedom. The appropriation of the mountains was tantamount to believing that pessimistic moods made it possible to achieve considerable psychological maturity.
\end{abstract}

Cóż za cudowny czas! Walter Scott był wtedy u szczytu powodzenia, poznawano tajemnice Fausta, który, jak powiada Pani de Staël, zawiera wszystko, a nawet trochę więcej niż wszystko. Odkrywano Szekspira w nieco poprawionym przekładzie. Letourneura i poematy lorda Byrona — przychodziły do nas ze Wschodu, który nie zbanalizował się jeszcze. [...] Czuliśmy zawrót głowy, zdawało się, że wkraczamy w światy nieznane ${ }^{1}$

- tymi słowami Teofil Gautier charakteryzował stan ducha bohemy artystycznej Paryża. Nie ulega wątpliwości, że odpowiadając na pytanie o początek dekadentyzmu w Europie - wiele symptomów wskazuje już na pierwszą połowę XIX wieku. Miał tego świadomość Ignacy Matuszewski, który w znanej (przełomowej) monografii poświęconej Juliuszowi Słowackiemu, zatytułowanej Słowacki i nowa sztuka (Modernizm). Twórczość Stowackiego w świetle estetyki nowoczesnej (1904), wskazał w refleksji autora Kordiana wspólnotę mentalną, zbliżoną

\footnotetext{
1 T. Gautier, Pisarze i artyści romantyczni, przeł. J. Guze, Warszawa 1975, s. 30.
} 
do światopoglądowych i estetycznych tendencji „schyłkowców”. Podkreślał przy tym podobne cechy estetyczne realizacji artystycznych Słowackiego, wymieniając „syntezę nastroju” ${ }^{2}$. To Słowacki właśnie jest autorem znanego polskim literaturoznawcom poematu $W$ Szwajcarii (1839), z którego pochodzi passus przywołany w tytule niniejszego referatu: „Za czarnych skał krawędzie”, gdzie podąża bohater liryczny — w dążeniu do samounicestwienia — poszukując ulgi w cierpieniu. Artur Schopenhauer, filozof romantyczny, a zarazem twórca teorii dekadentyzmu, w swoim najpopularniejszym dziele Świat jako wola i wyobrażenie usankcjonował wiecznotrwałą proweniencję gór jako antidotum dla kruchej materii ludzkiej:

Jeśli widok gór, otwierający się znienacka przed nami, tak łatwo wprawia nas w poważny i wzniosły nastrój, polega to może po części na tym, że kształt gór i wynikający stąd zarys pasma górskiego stanowi w widoku jedyną linię niezmienną, gdyż tylko góry opierają się zagładzie, która szybko dosięga wszystko inne, zwłaszcza naszą efemeryczną osobę. Nie żeby na widok gór pojawiło się wszystko to wyraźnie w naszej świadomości, lecz wywołuje ono mgliste przeczucie jako motyw przewodni naszego nastroju ${ }^{3}$.

Lektura tego fragmentu prowokuje przywołanie znanego wiersza poety młodopolskiego Tadeusza Micińskiego, który w Drodze do Kieżmarku również definiował rolę gór jako wiecznotrwałego symbolu nieskończoności:

Nieskończoność we mnie trwa -

lśnią szmaragdy czarnych borów -

lśnią szmaragdy czarnych borów.

Na kaskadzie nimfa łka

w grotach ciemnych wśród jaworów.

Od razu też zwraca uwagę podobne obrazowanie przestrzeni: czarne bory i ciemne jawory Micińskiego korespondują z czarnymi skałami Słowackiego.

Można zatem zasugerować, że wedle Schopenhauera wszystko na świecie podlega rozbiciu i rozkładowi — ale nie góry! Być może dlatego już sam widok gór, a co dopiero ich autopsyjne doświadczenie, stanowił w przypadku poetów zakorzenionych w ideałach dekadentyzmu ważny aspekt przezwyciężania własnych słabości, ocalenia sensu egzystencji. Wspomniany poemat Słowackiego, zaczynający się od incipitu „Odkąd zniknęla jak sen jaki złoty / Usycham z żalu, umieram z tęsknoty”, jest opowieścią o miłości i śmierci, sytuuje się zatem w kręgu ulubionej semantyki pisarzy zainspirowanych przez dekadentyzm. Kochanka zniknęła nagle z życia bohatera (nie wiadomo, czy umarła fizycznie, czy po prostu umarła dla niego, niczym dla Mickiewiczowskiego Gustawa). Intensywne przeżycia uczuciowe

${ }^{2}$ I. Matuszewski, Stowacki i nowa sztuka (Modernizm). Twórczość Stowackiego w świetle przejawów estetyki nowoczesnej, Warszawa 1911, s. 5.

3 A. Schopenhauer, Świat jako wola i przedstawienie, t. 2, przeł. J. Garewicz, Warszawa 1995, s. 579. 
rozgrywają się w idyllicznej scenerii górskiej przyrody i ta przestrzeń predestynuje bohatera lirycznego do uwznioślających, emfatycznych przeżyć na tle zmysłowo postrzeganych Alp. Śmierć (kochanki lub uczuć) konotuje zmianę alpejskiej scenerii pastelowej w wizyjne obrazy katastroficzne (przyroda otaczająca bohatera lirycznego zdaje się płakać i rozpaczać wspólnie $\mathrm{z}$ nim). W naturze i górskim pejzażu bohater poszukuje ukojenia oraz miejsca „na smutek łaskawego”. Animizowana górska natura jest partnerem rozpaczy (jak w przypadku każdego bohatera romantycznego). Dlatego księżyc rozświetlający kosmogonię tak energetycznie oddziałuje na jego duszę, że bohater znękany poczuciem utraty pozbędzie się udręki, gdyż stęskniony smutek sam z niego wyjdzie (czy raczej obrazowo zostanie z niego wyciągnięty przez antroponimizowany księżyc). I ta paradoksalna utrata smutku przynosi w efekcie nadzieję na odzyskanie równowagi psychicznej.

W tym kontekście poetycki fragment Słowackiego zinterpretował Mieczysław Karłowicz — przedstawiciel pokolenia Młodej Polski, jeden z najbardziej rozpoznawalnych polskich kompozytorów, fotograf, turysta wysokogórski, który zginął w Tatrach przygnieciony lawiną w 1909 roku. Osobowość artystyczna Karłowicza koresponduje z osobowością Słowackiego, z którego dorobku kompozytor wybrał XXI fragment przywołanego poematu. Pieśń znana pod tytułem Skąd pierwsze gwiazdy (op. $1 \mathrm{nr}$ 2) powstała w 1896 roku stanowi znakomity przykład korespondencji języka poetyckiego z fakturą melodyczną (rytmiczno-interwałowa struktura melodyczna odpowiada rytmice wiersza Słowackiego) ${ }^{4}$. Treść poetycka brzmi następująco:

Skąd pierwsze gwiazdy na niebie zaświecą,

Tam pójdę, aż za ciemnych skał krawędzie.

Spojrzę w lecące po niebie łabędzie

I tam polecę, gdzie one polecą.

Bo i tu — i tam — za morzem — i wszędzie,

Gdzie tylko poszlę przed sobą myśl biedną,

Zawsze mi smutno i wszędzie mi jedno;

I wszędzie mi źle - i wiem, że źle będzie.

Więc już nie myślę teraz, tylko o tem,

Gdzie wybrać miejsce na smutek łaskawe,

Miejsce, gdzie żaden duch nie trąci lotem

O moje serce rozdarte i krwawe;

Miejsce, gdzie księżyc przyjdzie aż pod ławę

Idąc po fali... zaszeleści złotem

I załoskocze tak duszę tajemnie,

Że stęskni — ocknie się i wyjdzie ze mnie ${ }^{5}$.

${ }^{4}$ Ibidem, s. 132.

5 J. Słowacki, Skąd pierwsze gwiazdy, cyt. za: M. Karłowicz, Pieśni [op. 1, 3, 4 i bez opusu], Kraków 2016, s. 10-11. 
Wiersz emanuje charakterystycznym dla Słowackiego plastycznym sposobem obrazowania (złoto gwiazd, srebro księżyca, ciemne niebo, białe łabędzie kształtują zmysłową impresję) oraz sprecyzowaną (typowo romantyczną) sytuacją egzystencjalną nieustabilizowanego psychicznie podmiotu lirycznego, któremu permanentnie smutno i źle z powodu nieszczęśliwej miłości (czy raczej śmierci uczuć?). Księżyc jako element romantycznej kosmogonii ma nim wstrząsnąć wewnętrznie (załoskotać jego duszą), by „wyciągnąć” z niego smutek. $\mathrm{Z}$ jednej strony - bohater wydaje się oswojony $\mathrm{z}$ tym przygnębieniem, $\mathrm{z}$ drugiej — pragnie się z niego wyzwolić. Jego przyszłość jest niepewna, tajemnicza i mało optymistyczna, bowiem musi on wejść „aż za ciemnych skał krawędzie”. Można ów proces określić jako specyficzny stan psychomachii (walki ze słabością charakteru, z ograniczeniami psychicznymi), zmierzającej ku pesymistycznej otchłani wszechbytu („Wiem, że źle będzie” — deklaruje jednoznacznie bohater). Kolorystyka Słowackiego współgra tutaj z kolorystyczną harmoniką Karłowicza ${ }^{6}$. Mieczysław Tomaszewski sugeruje, że w warstwie słownej tekstu można wyznaczyć trzy pola semantyczne: pójdę, gdzie gwiazdy; polecę, gdzie łabędzie; bo zawsze mi smutno i wszystko mi jedno i wiem, że źle będzie ${ }^{7}$. Wypada zaproponować nieco inną interpretację. Pełna ciężkich akordów partia fortepianu i fortepianowa przygrywka wprowadzają $\mathrm{w}$ dramat sytuacji: dekadencki bohater nie tyle leci w gwiazdy, ile chowa się „,za czarnych skał krawędzie”, wprawdzie leci, gdzie łabędzie, ale po to, żeby zdiagnozować stan zobojętnienia, że zarówno tu, jak za morzem - wszystko mu jedno, wprawdzie pesymistycznie orzeka, że źle będzie, lecz zwróćmy uwagę na ciekawą muzyczną strukturę tej konkluzji. W ostatnich taktach pieśni kantylena wznosi się ku górze, oddając klimat wyzwalającej nadziei i katharsis smutku (podobnie jak w wierszu Słowackiego żal po utracie zyskuje wyraz muzyczny). Pieśń charakteryzuje duża kondensacja napięcia emocjonalnego. Pauzy, zróżnicowana intonacja, podkreślenie inwersji w tekście poetyckim - wszystko to dopełnia dekadenckie doświadczenie gór jako przestrzeni symbolizującej tajemnicę ludzkich słabości, lęków i próby ich pokonywania. Bohater Słowackiego obserwuje gwiazdy, księżyc i uciekające za szczytami łabędzie. Poziom obserwacji przechodzi z linii horyzontalnej w wertykalną, co potwierdza, że dekadencki artysta przeżywa mękę mistycznych wtajemniczeń, wyje z bólu egzystencjalnego, a zarazem nonszalancko przechadza się nad przepaścią, pozbawiony instynktu samozachowawczego - wspina się na niebosiężne szczyty, które zawłaszcza jako przestrzeń przeznaczoną wyłącznie dla niego - osiąga cele wyższe, niedostępne zwykłym śmiertelnikom. Karłowicz, który kochał Tatry i samotność na łonie przyrody — uciekał w nie, by odnaleźć wyzwalające poczucie wolności. Jak pisał:

${ }^{6}$ Utwór został szczegółowo zanalizowany przez Barbarę Chmarę-Zaczkiewicz, [w:] Z życia i twórczości Mieczysława Karłowicza. Studia i materiały, red. E. Dziębowska, Warszawa 1970, s. 136.

${ }^{7}$ M. Tomaszewski, Nad pieśniami Mieczysława Karłowicza, [w:] Muzyka polska a modernizm, Kraków 1981, s. 130. 
Leżąc tutaj na wonnej łące, w cudowny dzień lipcowy, doznałem wrażenia, tak obcego mieszkańcom równin: uczucia nieograniczonej wolności. Zapomniałem o drobiazgach życia codziennego, zapomniałem o drobnych nadziejach, marzeniach, zawodach. Tutaj, wobec otaczających mnie gór, czułem się tak małym, takim pyłkiem, że opanowała mnie żądza dążenia do rzeczy wielkich i szlachetnych. W tej dziwnej ciszy czerpałem siły na przyszłe, nieuniknione zapasy z losem i czułem, że każdy, kto by potrzebował spokoju i odpoczynku po pracy, tutaj wróciłby w jednej chwili do siebie ${ }^{8}$.

Nic dziwnego, że wybrany fragment Słowackiego musiał być dla Karłowicza ważny. Warto też dopowiedzieć, że w pierwszą rocznicę śmierci kompozytora, w 1910 roku, matka Karłowicza (Irena Karłowiczowa) informowała Paulinę Dicksteinową, że grupa narciarzy chce złożyć wieniec w miejscu śmierci nad Czarnym Stawem, gdzie zamierzali odśpiewać pieśń Ską pierwsze gwiazdy ${ }^{9}$.

$\mathrm{Z}$ dorobku artystycznego Karłowicza należy również wydobyć inne pieśni (traktowane przez muzykologów marginalnie), skomponowane do słów znanych polskich poetów dziewiętnastowiecznych, głównie Kazimierza Przerwy-Tetmajera jako czołowego polskiego wyraziciela dekadentyzmu w poezji. Karłowicz reprezentował wprawdzie neoromantyczną wersję modernizmu w muzyce, dlatego w jego twórczości zwracają uwagę analogie romantyczne (emocjonalizm, mistycyzm, indywidualizm, ekspresja formy) i niewątpliwie osobowościowe cechy introwertyka i indywidualisty izolowały go od pokoleniowych utożsamień już w okresie studiów berlińskich. Niemniej z pokoleniem młodopolan identyfikował się poprzez nastrojowość (dążenie do osiągnięcia nirwany przezwyciężającej stany depresji i deprywacji, pokonania śmierci przez wiarę w wyzwalającą siłę przyrody, ujawnia się tu też typowo młodopolska afirmacja przyrody jako emanacji sacrum).

W nastrojowości tych utworów zwraca uwagę powracający (typowo dekadencki) pesymizm - dominujący w muzyce Karłowicza. O inspiracjach czerpanych z twórczości Asnyka i Tetmajera świadczy nastawienie kontemplacyjne i medytacyjne jego utworów. Warto przypomnieć, że jednym z ulubionych Tetmajerowskich lektur Karłowicza był wiersz $\mathrm{Na}$ „Żelaznej Drodze” pod Reglami, gdzie poeta w udanych neologizmach (rozszerzać, rozdalać, rozpływać) hiperbolizuje abstrakcyjne (metafizyczne) pojęcie wszechbytu unicestwiającego „zmaterializowaną" duszę artysty. Góry w tym wierszu stają się desygnatem metafizycznych wzlotów i impresji. Tekst jest znakomitym przykładem przełamywania się romantycznej i młodopolskiej filozofii pejzażu. Otwiera dekadenckiego odbiorcę wrażeń nie tylko na przeżycia estetyczne (jak w konwencji romantycznej), lecz

${ }^{8}$ Mieczysław Karlowicz w Tatrach. Pisma taternickie i zdjęcia fotograficzne, Kraków 2016, s. 11.

${ }^{9}$ List Ireny Karłowiczowej do Pauliny Dicksteinowej z 2 lutego 1910 roku, [w:] Mieczystaw Karlowicz w listach i wspomnieniach, oprac. H. Anders, Warszawa 1960, s. 642. 
również na nieskończoność, metafizykę różnorodnych objawien ${ }^{10}$. Drobnym tropem górskim w pieśni Idzie na pola do słów Kazimierza Tetmajera jest obecność ośnieżonych szczytów górskich, ciemnych borów, sinych strumieni i bladego księżyca. Karłowicz w formie ballady definiuje „muzykę duszy” — tutaj również nasuwają się konotacje z innym wierszem Słowackiego (Anioł ognisty - mój anioł lewy), w którym wywołane zostało zjawisko „duszy muzycznej”.

Idzie na pola, idzie na bory,

Na łąki i na sady,

Na sine wody, na śnieżne góry,

Na miesiąc idzie blady;

Idzie w niezmierną otchłań wszechświata,

Skąd pył dróg mlecznych prószy,

Idzie błękitna, cicha, skrzydlata -

Muzyka mojej duszy ${ }^{11}$.

Tetmajerowska muzyka, która się wyłania z głębi duszy w interpretacji Karłowicza, jest utrzymana w pogodnym rytmie, umiarkowanym tempie i napawa pozytywnymi emocjami, gdyż jest to przestrzeń, która ocala i pozwala znaleźć ukojenie. „Ochłodę znalazłem przy śniegu, nad drobnym stawkiem, położonym powyżej Stawu Żółtego"12 — pisał Karłowicz w jednej ze swych relacji z górskich wycieczek. Mało istotne jest, że muzyka ,idzie w niezmierną otchłań wszechświata", bowiem ta otchłań nie jest destrukcyjna. Dlatego - podobnie jak w poprzedniej pieśni - Karłowicz zastosował ten sam chwyt w ostatniej kadencji utworu, w którym również linia melodyczna wnosi się ku górze, pozostawiając wrażenie nieskończonego trwania tego procesu. „Upaja mnie ten lot... ta nicość” 13 — pisał Tetmajer w Otchłani. Lecz powieść wydana w 1900 roku powstała cztery lata po pieśniach Karłowiczowskich. I w zasadzie podobnie Karłowicz postąpił w kolejnej pieśni napisanej do znanego erotyku Tetmajerowskiego Zawód (rozpoczynającego się od incipitu „Wykołysałem cię wśród fal”), stanowiącego dobry przykład metaforyki marynistycznej zastosowanej dla oddania górskiego sztafażu (wszak kochanka porównana jest do „limby nadwodnej”) — słonecznego zjawiska, do którego bohater tęskni, patrząc na górskie hale, poranne mgły górskie i w otoczeniu górskiej przyrody — tak jak bohater Słowackiego — wyraża żal z powodu utraconej miłości (śmierci uczuć).

Wykołysałem cię wśród fal mych snów, jak limbę gdzieś nadwodną, śniłem cię cichą i pogodną - ah! jak mi żal, jak żal...

10 Por. J. Prokop, Żywioł wyzwolony. Studium o poezji Tadeusza Micińskiego, Warszawa 1978, s. 61 .

11 K. Przerwa-Tetmajer, Idzie na pola, cyt. za: M. Karłowicz, op. cit., s. 20.

12 Mieczystaw Karlowicz w Tatrach..., s. 121.

13 K. Przerwa-Tetmajer, Otchtań, Warszawa 1900, s. 108. 
Na zieloności sennych hal, gdzie wiatr błękitne mgły rozpina, byłaś mi, dziewczę, tak jedyna — ah! jak mi żal, jak żal...

Wkoło szumiały smreki w dal jakiemś modleniem cichem, wiecznem byłaś mi tam czemś tak słonecznem - ah! jak mi żal, jak żal... ${ }^{14}$

Lecz ów stęskniony żal Karłowicz również wyraził w górnych tonacjach melodycznych i w umiarkowanym, wyciszonym, spokojnym tempie. Nie jest to zatem żal destrukcyjny, być może dekadencki artysta korzysta z takich właśnie doświadczeń emocjonalnych w celu udowodnienia, że potrzebuje gór, by się wyzwolić.

Dla potwierdzenia omawianego zjawiska warto przywołać przykład innej pary autorskiej, a mianowicie - wiersz Na księżycu czarnym wiszę Tadeusza Micińskiego (z tomu $W$ mroku gwiazd, 1902) stanowiący podstawę tekstową pieśni Karola Szymanowskiego (Sześć pieśni do słów T. Micińskiego, op. 20).

Na księżycu czarnym wiszę

patrząc $\mathrm{w}$ gwiazd gasnących ciszę.

W mroku dumnym i bezgłośnym

ze strzaskaną harfą snów

płynę - szukam jej -

nie odnajdę już ${ }^{15}$.

Tutaj bohater, zakorzeniony w mroku (gwiazdy gasną, zobrazowany oksymoronicznie czarny księżyc nie wyciągnie $\mathrm{z}$ niego smutku, jak w przypadku Słowackiego) i bezdźwięcznej ciszy, przeżywa kryzys artystyczny: zgubił harfę i przewiduje, że bezpowrotnie. Popada zatem w beznadziejną niemoc twórczą. W pieśni Szymanowskiego zostało to wypowiedziane w intonacji nieprzekonującej, bo również wspinającej się ku górze. Krótka osiemnastotaktowa pieśń jest zaliczana do tych utworów wokalnych autora Harnasi, którą wyróżnia intensyfikacja ekspresji muzycznej, widoczna w koncentrycznym rozplanowaniu dynamiki. Powtarzalność jako zasada redukcji widoczna jest zwłaszcza w kształtowaniu melodyki, którą tworzy właściwie jedna opadająca na ogół sekundami fraza, wyzyskana sześciokrotnie dla sześciu wersów tekstu Micińskiego. Ciemny tajemniczy koloryt pieśni rozjaśnia i przyciemnia miejscami chromatyczno-enharmoniczna zmiana akordu. W ten sposób kształtuje się efekt wiecznego trwania wywołanych emocji na tle wiecznotrwałej górskiej przyrody.

Znamienne, że wszyscy przywołani tu poeci (z wyjątkiem romantycznego Słowackiego) i kompozytorzy byli związani z nurtem Młodej Polski Tatrzańskiej bądź mieszkali czasowo u stóp Tatr — w Zakopanem, mniej więcej w tym

14 K. Przerwa-Tetmajer, Zawód, cyt. za: M. Karłowicz, op. cit., s. 15.

15 T. Miciński, Na księżycu czarnym wiszę, [w:] idem, W mroku gwiazd, Kraków 1902, s. 27. 
samym okresie. Jeżeli chodzi o twórczość kompozytorów, to — jak pisał Adolf Chybiński -

Nie Podhale, lecz Tatry interesowały ich w pierwszym rzędzie. Tatry jako piękne obrazy przyrody, dające silne wrażenie i twórcze impulsy dla pewnych typów twórczych, a zarazem dające możność muzycznej stylizacji różnych akustycznych zjawisk (odgłosy natury), uplastyczniających wyraz nastroju ${ }^{16}$.

Wydaje się, że poezja Tetmajera, Micińskiego, Staffa, Kasprowicza inicjowała w nich te wrażenia.

Góry w przekonaniu polskich modernistów były symbolem wieczności i potęgi natury, przeciwstawianym kruchości ludzkiej egzystencji, oazą ciszy, spokoju i samotności, a więc i wolności człowieka. Zawłaszczanie górskiej przestrzeni było równoznaczne $\mathrm{z}$ odwiedzinami siedziby młodych bogów - zdobywców transcendencji, piewców nowego życia, odkrywców, że pesymistyczne nastroje mogą wprowadzić constans, że można w nich trwać, by w cierpieniu osiągnąć większą dojrzałość i epatować smutkiem jako nieodłączną kondycją ludzkiej psychiki. Wydaje się, że góry pomogły dekadenckim artystom przełamać wewnętrzny bunt i zaakceptować stany depresyjne, postawy lękowe, poczucie niemocy twórczej. To kolejny dowód na to, że górski monumentalizm może stanowić siłę wręcz narkotyczną.

\section{Bibliografia}

Chybiński A., Karol Szymanowski a Podhale, [w:] O Karolu Szymanowskim. Antologia, oprac. Z. Sierpiński, Warszawa 1983.

Gautier T., Pisarze i artyści romantyczni, przeł. J. Guze, Warszawa 1975.

Karłowicz M., Pieśni [op. 1, 3, 4 i bez opusu], Kraków 2016.

Matuszewski I., Słowacki i nowa sztuka (Modernizm). Twórczość Słowackiego w świetle przejawów estetyki nowoczesnej, Warszawa 1911.

Miciński T., W mroku gwiazd, Kraków 1902.

Mieczystaw Karlowicz w listach $i$ wspomnieniach, oprac. H. Anders, Warszawa 1960.

Mieczysław Karłowicz w Tatrach. Pisma taternickie i zdjęcia fotograficzne, Kraków 2016.

Prokop J., Żywioł wyzwolony. Studium o poezji Tadeusza Micińskiego, Warszawa 1978.

Przerwa-Tetmajer K., Otchtań, Warszawa 1900.

Schopenhauer A., Świat jako wola i przedstawienie, t. 2, przeł. J. Garewicz, Warszawa 1995.

Tomaszewski M., Nad pieśniami Mieczysława Karlowicza, [w:] Muzyka polska a modernizm, Kraków 1981.

Z życia i twórczości Mieczysława Karłowicza. Studia i materiały, red. E. Dziębowska, Warszawa 1970.

16 A. Chybiński, Karol Szymanowski a Podhale, [w:] O Karolu Szymanowskim. Antologia, oprac. Z. Sierpiński, Warszawa 1983, s. 133. 